Publisher homepage: www.universepg.com, ISSN: 2663-6913 (Online) \& 2663-6905 (Print)

\title{
Evaluation of Some Fungicides against Collar Rot Disease of Soybean
}

\author{
Md. Maksuder Rahman ${ }^{1}$, Mahbuba Kaniz Hasna ${ }^{2}$, Nahar Shumsun ${ }^{1}$, Raqibul Hasan ${ }^{1}$, Md. Nazizul \\ Islam $^{3}$, Md. Humayun Kabir ${ }^{1}$, and Mohammad Delwar Hossain ${ }^{1} *$ \\ ${ }^{1}$ Department of Plant Pathology, Bangladesh Agricultural University, Mymensingh, Bangladesh; ${ }^{2}$ Plant Pathology \\ Division, Bangladesh Institute of Nuclear in Agriculture, Mymensingh, Bangladesh; and ${ }^{3}$ Department of Environmental \\ Science, Bangladesh Agricultural University, Mymensingh, Bangladesh. \\ *Correspondence: delwarmhossain@gmail.com (Dr. Mohammad Delwar Hossain, Professor, Dept. of Plant Pathology, \\ Bangladesh Agricultural University, Mymensingh. Bangladesh).
}

\begin{abstract}
A number of selected fungicides were evaluated to determine their efficacy for controlling collar rot disease of soybean plants caused by Sclerotium rolfsii. The experiment was conducted under the controlled condition at the Plant Pathology Laboratory and Field laboratory of BINA, Bangladesh Agricultural University campus from November 2018 to August, 2019. In-vitro research was done for the observation of radial mycelial growth of $S$. rolfsii on potato dextrose agar (PDA), treated with five fungicides viz. Antracol 70 WP (T1), Ridomil Gold MZ 68 WP (T2), Secure 600 WG (T3), Bavistin DF (T4), Dithane M-45 (T5) and one non-treated (T0) treatment. The highest percentage of mycelial growth inhibition of $S$. rolfsii in PDA medium was recorded in treatment T5 (Dithane M-45) 100\% and lowest in treatment T3 (Secure 600 WG) $37.33 \%$ at 6 days after inoculation. Then the selected five fungicides were again applied to pot under controlled conditions to observe the best effect of selected fungicides against collar rot pathogen of soybean plants. The inoculation was done on a variety of BINA soybean 4 in pot condition. The highest mortality percent for the collar rot disease was found in treatment T0 (controlled) 100\% soybean plants conversely, the lowest mortality percent was found in treatment T5 (Dithane M-45) $27.28 \%$ besides $38.92 \%$ in T2 (Ridomil Gold MZ $68 \mathrm{WP}$ ), 43.42\% in T1 (Antracol $70 \mathrm{WP}$ ), 46.18\% in T3 (Secure $600 \mathrm{WG)} \mathrm{and} \mathrm{50.00 \%} \mathrm{in}$ treatment T4 (Bavistin DF) respectively. Thus, Dithane M-45 was found superior in controlling collar rot pathogen $S$. rolfsii of Soybean over all other fungicides tested in both in vitro and in vivo.
\end{abstract}

Keywords: Fungicide, Collar rot disease, Sclerotium rolfsii, Evaluation, and Soybean.

\section{INTRODUCTION:}

Soybean (Glycine max L. Merr.) is a leguminous crop and a good source of protein and vegetable oil. Soybean is providing $40 \%$ protein. It can play a vital role in balancing the protein deficiency of our diet (Mondal and Wahhab, 2001; Rahman, 2003). Soybean production of Bangladesh is $1.59 \mathrm{t} / \mathrm{ha}$ which is much lower than the world average $(2.53 \mathrm{t} / \mathrm{ha})$ (FAO, 2013). Soybean raw materials are used in different industries. Different soya foods are also prepared from soybean (Hossain et al., 1992).
Soybean can fix to an extent of $300 \mathrm{~kg}$ Nitrogen/ ha/year and reduce the nitrogen requirement by 25 $75 \%$ with Bradyrhizobium japonicum. Moreover, Soybean can fix atmospheric nitrogen symbiotically and therefore, through symbiosis about $80-90 \%$ nitrogen demand could be supplied by soybean (Keyser and Li, 1992). Thus this crop enhance soil fertility and economizes crop production not only for themselves but also for the next cereal crops and other non-legume crops grown in rotation and thereby, minimizing the regular rate of nitrogen fertilizer. 
The production of soybean plants is low due to disease constrains. Soybean plants suffer from many diseases for example anthracnose, mosaic, collar rot, powdery mildew, etc. Out of them collar rot/ Foot and root rot of soybean is very severe damaging disease in Bangladesh, which is caused by $S$. rolfsii. It is common where high temperatures exist during the rainy season. The pathogen causes pre emergence and post emergence damping off, foot and root rot, collar rot and wilt of seedlings. Collar rot can occur in both seedling and adult plants. Collar rot /Foot and root rot disease is more common than southern blight or stem rot form in our country. Southern blight form of the diseases usually occurs on the older plants (Ahmed and Hossain, 1985). $S$. rolfsii, has the wide host range of more than 500 species of plants including many important crops such as maize, wheat, gram, khesari, lentil, mashkalai, mungbean, sunflower, sesame, brinjal, bitter gourd, bottle gourd, cowpea, cucumber, okra, radish, tomato, radish, chilli, coriander, garlic, onion, apple, peanut, soybean, and potato ; also many woody ornamentals, herbaceous annuals and perennials including ageratum, aucuba, azalea, begonia, columbine, coneflower, forsythia, hydrangea, marigold pansy, petunia, viburnum, and zinnia (Punja, 1985; Mullen, 2001).

Sclerotium rolfsii is both seed borne and soil borne pathogen (Fakir et al., 1991). Collar rot causes yield loss of $10-25 \%$, but under severe diseased conditions yield losses may ranges from 50 to $80 \%$ (Patil and Rane, 1982). It is very difficult to manage the pathogen because of its diverse nature of survival as large number of sclerotia produced and their ability to persist in the soil for several years. The fungus causes $25-50 \%$ loss through infection of seedlings. To control the fungus people usually use many chemicals. But the fungus $S$. rolfsii is a facultative saprophyte and can maintain continuity of its generation under adverse situation by the formation of sclerotia (Ahmed, 1980). Varietal resistance is another option for diseases management (Singh et al., 2002). But there is no soybean resistant variety against collar rot in Bangladesh. So, it is necessary to search out effective fungicides to control this devastating disease. That's why the present research was taken under consideration to select the effective fungicides in vitro (Laboratory experiment) and in vivo (Pot Experiment) against collar rot disease of soybean caused by S. rolfsii.

\section{MATERIALS AND METHODS:}

The experiments were conducted during 2018 to 2019 in CRD design with thrice replication.

\subsection{In-vitro evaluation (Laboratory Experiment) of different fungicides against Sclerotium rolfsii:}

Poisoned food technique was used for evaluating the fungicidal effects on the growth of collar rot pathogen $S$. rolfsii. Five different fungicides viz., Antracol 70 WP (Propineb), Bavistin DF (Carbendazim), Dithane M-45 (Mancozeb), Secure 600 WG (Mancozeb and Fluazinam), Ridomil Gold MZ 68 WP (Mancozeb and Metalaxyl) were included in the experiment. The fungicides solutions were prepared in accordance with the labeled doses in the fungicide formulation. For example, preparation of $0.2 \%$ Antracol solution, $2 \mathrm{~g}$ of Antracol was taken into $1000 \mathrm{ml}$ of sterilized distilled water. Poison food technique with little modification was followed for the evaluation of selected fungicides against $S$. rolfsii. Preparation of PDA containing fungicides was done in two steps.

In first step, clean peeled slice potato tubers of $125 \mathrm{~g}$ were boiled in $500 \mathrm{ml}$ of water. Water was sieved from boiled potato slices and $10 \mathrm{~g}$ agar and $10 \mathrm{~g}$ Dextrose were added to it. PDA suspension was prepared up to $1000 \mathrm{ml}$ of sterilized media before pouring in petridishes for preparing the original concentration. For preparation of poison food media $0.2 \mathrm{~g}$ fungicide was mixed with $99.8 \mathrm{ml}$ PDA media (Nene and Thapliyal, 1982). Isolation of the $S$. rolfsii was done by following standard tissue planting method from infected soybean plants. The infected tissues of soybean plants showing typical collar rot symptoms planted on potato dextrose agar (PDA) medium. The petriplates were incubated at $28+2^{\circ} \mathrm{C}$ were observed periodically for growth of the fungus. Pure culture of $S$. rolfsii was maintained on PDA slants for further studies. The pathogen was identified based on its mycelial and sclerotial characteristics (Sekhar et al., 2017). The amended medium was then poured in sterilized Petri dish (90 $\mathrm{mm}$ dia.). A 5-7 $\mathrm{mm}$ disc of test fungus cut from the margins of ten days old cultures were placed centrally in each of the Petri dish and were incubated at $27^{\circ} \mathrm{C}$. Mycelial growth colony diameter of $S$. rolfsii was measured at two days interval. It took 12 days to coverage of petridishes by mycelia. The percent mycelia growth inhibition (PI) of the fungus over control was calculated by using following 
formula (Vincent, 1927). PI = C-T/C $\times 100$. Where, $\mathrm{C}=$ Growth of test pathogens in absence of fungicides $(\mathrm{mm}), \mathrm{T}=$ Growth of test pathogens in presence of fungicides $(\mathrm{mm})$. The diameter was measured with $\mathrm{mm}$ scale from the back side of the petridish taking it opposite to light.

2.2 In-vivo evaluation (Pot Experiment) of different fungicides against Sclerotium rolfsii: The in vivo evaluation of different fungicides was conducted in controlled conditions in the Field laboratory during April, 2019 to October, 2019. The experimental field was medium high land and the soil was sandy loamy. The experimental site belongs to Brahmaputra Alluvial Tract, the PH was 7.5. The soil of the experiment was collected from BINA farm field and then sun-dried, ground and screened through 10 mesh sieve to remove large particles and debris. The soil was dripped with $2 \%$ formalin solution 200ml per cft soil and kept covered with polythene sheets for 2-3 days. Then the soil was uncovered and kept for 4 days to release the gas formalin. Collected BINA soybean 4 seeds (10 seeds) were taken on a wet blotter paper in a petridish and kept for 4-7 days. Then the germination percent was $100 \%$ calculated by the formula of (Pankaj et al., 2016):

Germination $(\%)=$ Number of Total Germinated Seeds / Total Number of Seeds Tested $\times 100$.
The seeds were treated with provax $2000.2 \%$ before sowing. The soil was poured into perforated plastic pots at the rate of $11.50 \mathrm{~kg} / \mathrm{pot}$ for 6 treatments including control. The following fertilizers (Table 1) were applied in each pot as per recommendation dose of the fertilizers Recommendation Guide (BARC, 2012) and total fertilizer were mixed uniformly and $5.22 \mathrm{~g} /$ pot were given two days before seed sowing.

Table 1: Fertilizers and recommended doses.

\begin{tabular}{|l|c|c|}
\hline Fertilizer & Doses (kg/ha) & Dose (g/pot) \\
\hline Urea & 60 & 0.62 \\
\hline TSP & 175 & 1.82 \\
\hline MP & 120 & 1.25 \\
\hline Gypsum & 115 & 1.20 \\
\hline Zinc Sulphate & 6 & 0.062 \\
\hline Boric acid & 10 & 0.104 \\
\hline
\end{tabular}

The pots were tagged according to treatments received. Five fungicides (Table 2) were selected for pot experiment based on laboratory performance. Total six treatments were applied including control. There were 3 replications of each treatments and pots with fungicidal subsequent foliar spray.

Table 2: Different treatments along with mode of action, active ingredients, percent concentration and application rate (in-vitro).

\begin{tabular}{|l|l|c|c|}
\hline Treatments & \multicolumn{1}{|c|}{ Active ingredient } & Mode of action & Application rate \\
\hline $\mathrm{T}_{0}=$ Control & \multicolumn{1}{|c|}{-} & - \\
\hline $\mathrm{T}_{1}=$ Antracol 70 WP & Propineb 70\% & Contact & $2 \mathrm{~g} / \mathrm{L}$ \\
\hline $\mathrm{T}_{2}=$ Ridomil Gold MZ 68 WP & Mancozeb 64\% and Metalaxyl 8\% & Systemic, Contact & $2 \mathrm{~g} / \mathrm{L}$ \\
\hline $\mathrm{T}_{3}=$ Secure 600 WG & Mancozeb 50\% and Fluazinam 40\% & Contact & $1 \mathrm{~g} / \mathrm{L}$ \\
\hline $\mathrm{T}_{4}=$ Bavistin DF & Carbendazim 50\% & Systemic & $1 \mathrm{~g} / \mathrm{L}$ \\
\hline $\mathrm{T}_{5}=$ Dithane M-45 & Mancozeb 80\% & Systemic & $2 \mathrm{~g} / \mathrm{L}$ \\
\hline
\end{tabular}

Seeds of soybean and required amount of individual selected fungicides (Provax) were taken in a petridish. Then few drops of sterilized water were added and shaken well with hands for few minutes and then kept open for drying. Then the seeds appeared to be coated with fungicides. Twenty-five seeds were sown in each pot on 28th June, 2019 and thinning was done at 15 DAS to maintain optimum plant UniversePG I www.universepg.com population. At least 15-20 seedlings were kept for data collection. All the recommended agronomical and intercultural practices were strictly followed and the crop was given protective irrigation as and when necessary. Mass inoculums of $S$. rolfsii was prepared as described by (Giri et al., 2003). In briefly, 500g lentil seeds were washed under sterilized water and taken into $1000 \mathrm{ml}$ conical flask. Then pure culture 
of $S$. rolfsii was inoculated and incubated for 12 days at room temperature and prepared $2 \%$ inoculums. Fungicidal spray was done on July 25, 2019 and $S$. rolfsii inoculum was sprayed on the collar region of each seedling $30 \mathrm{ml} /$ pot on August 08, 2019. The experiment was monitored regularly to observe the first appearance of Collar rot. Spraying of fungicides was applied on twice sprays at weekly interval on July and August, 2019 by the sprayer (Siddique, 1997; Yaqub and shahzad, 2006). Mortality percent was assessed with proper formula:

Mortality $(\%)=$ Number of dead plants in a pot/Total number of plants in pot $\times 100$.

2.3 Data Analysis - The data obtained from this research work were statistically analyzed following MSTAT-C program and treatment means in ANOVA tables were compared by LSD $(0.05 \%)$ as followed by Gomez and Gomez (1984).

\section{RESULT AND DISCUSSION:}

The results were compiled based on the inhibition of radial mycelial growth and mortality percent of soybean plants. The collar rot symptoms of soybean plants showed mycelium covering the plant stem near the soil surface. The pathogen produced cottony mycelium with small brown sclerotia on the infected plant parts revealed the collar rot disease symptoms. Later, affected plants/branches turned yellow or drooped while retaining their green color, followed by drying and turning straw colored. White mycelial strands appeared at the collar region and above, covering the base of the branches. Whitish, brownish, irregular shaped sclerotia mingled with mycelial strands on branches. The similar findings were described by Rekha et al. (2012), Kokub (2007), Prabhu and Patil (2004), Gupta and Sharma (2000), etc. The pathogen S. rolfsii was found whitish in colour in culture media and small mustard seed like sclerotia also found. The infected seedlings also showed cortical decay at the collar region and whitish mycelium was found extended on the soil surface. These findings were supported by Kulkarni et al. (1995), Aken and Dashiell, (1991), and Baruah et al. (1980).

3.1 In vitro evaluation (Lab experiment) - Efficacy of different treatments on radial mycelial growth of $S$. rolfsii was shown in Table 3. Fungicides have profound effect on reduction of radial mycelial growth of S. rolfsii. Here, it was observed that all the tested five fungicides significantly reduced the radial mycelial growth of $S$. rolfsii ranged from 0 to $45 \mathrm{~mm}$ recorded at 6 days after inoculation (DAI). The lowest radial mycelial growth $(0 \mathrm{~mm})$ of $S$. rolfsii was recorded in case of Dithane M-45 at 1,2, 3 and 6 DAI. The lowest radial mycelial growth was observed in treatment T5 (Dithane M-45) $0 \mathrm{~mm}$ followed by treatment T4 (Bavistin DF) $15.8 \mathrm{~mm}$, T1 (Antracol $70 \mathrm{WP}$ ) $16.5 \mathrm{~mm}, \mathrm{~T} 2$ (Ridomil Gold MZ 68 WP) $26.3 \mathrm{~mm}$ and T3 (Secure $600 \mathrm{WG)} 28.2$ $\mathrm{mm}$ after 6 DAI. Maximum radial mycelial growth $(45 \mathrm{~mm})$ was recorded in untreated T0 (Control) at 6 DAI. Again, the lowest radial mycelial growth of $S$. rolfsii was recorded in treatment T5 (Dithane M-45) $0 \mathrm{~mm}$ followed by treatment T4 (Bavistin DF) 22.2 mm, T1 (Antracol $70 \mathrm{WP}$ ) $23.9 \mathrm{~mm}, \mathrm{~T} 3$ (Secure 600 WG) $34.9 \mathrm{~mm}$ and T2 (Ridomil Gold MZ $68 \mathrm{WP}$ ) $35.5 \mathrm{~mm}$ after $10 \mathrm{DAI}$. The highest radial mycelial growth $(45 \mathrm{~mm})$ was recorded in untreated $\mathrm{T} 0$ (Control) again at $10 \mathrm{DAI}$.

Table 3: Evaluation of different fungicides against mycelial growth of Sclerotium rolfsii (in vitro).

\begin{tabular}{|c|c|c|c|c|c|c|c|c|}
\hline Treatments & \multicolumn{7}{|c|}{ Mycelial Growth of Sclerotium rolfsii on PDA Plate (mm) } \\
\cline { 2 - 10 } & $\mathbf{0 2 . 0 4 . 1 9}$ & $\mathbf{0 3 . 0 4 . 1 9}$ & $\mathbf{0 4 . 0 4 . 1 9}$ & $\mathbf{0 7 . 0 4 . 1 9}$ & $\mathbf{0 8 . 0 4 . 1 9}$ & $\mathbf{0 9 . 0 4 . 1 9}$ & $\mathbf{1 0 . 0 4 . 1 9}$ & $\mathbf{1 1 . 0 4 . 1 9}$ \\
\hline $\mathrm{T}_{0}$ & $10.60 \mathrm{a}$ & $19.20 \mathrm{a}$ & $28.90 \mathrm{a}$ & $45.00 \mathrm{a}$ & $45.00 \mathrm{a}$ & $45.00 \mathrm{a}$ & $45.00 \mathrm{a}$ & $45.00 \mathrm{a}$ \\
\hline $\mathrm{T}_{1}$ & $7.50 \mathrm{bc}$ & $10.70 \mathrm{c}$ & $11.30 \mathrm{c}$ & $16.50 \mathrm{c}$ & $20.80 \mathrm{c}$ & $21.00 \mathrm{c}$ & $23.00 \mathrm{c}$ & $23.90 \mathrm{c}$ \\
\hline $\mathrm{T}_{2}$ & $9.00 \mathrm{ab}$ & $13.20 \mathrm{~b}$ & $16.60 \mathrm{~b}$ & $26.30 \mathrm{~b}$ & $29.20 \mathrm{~b}$ & $31.30 \mathrm{~b}$ & $33.80 \mathrm{~b}$ & $35.50 \mathrm{~b}$ \\
\hline $\mathrm{T}_{3}$ & $6.60 \mathrm{c}$ & $12.20 \mathrm{~b}$ & $17.80 \mathrm{~b}$ & $28.20 \mathrm{~b}$ & $29.80 \mathrm{~b}$ & $30.10 \mathrm{~b}$ & $34.80 \mathrm{~b}$ & $34.90 \mathrm{~b}$ \\
\hline $\mathrm{T}_{4}$ & $6.16 \mathrm{c}$ & $10.30 \mathrm{c}$ & $11.70 \mathrm{c}$ & $15.80 \mathrm{c}$ & $19.20 \mathrm{c}$ & $20.00 \mathrm{c}$ & $21.90 \mathrm{c}$ & $22.20 \mathrm{c}$ \\
\hline $\mathrm{T}_{5}$ & $0.00 \mathrm{~d}$ & $0.00 \mathrm{~d}$ & $0.00 \mathrm{~d}$ & $0.00 \mathrm{~d}$ & $0.00 \mathrm{~d}$ & $0.00 \mathrm{~d}$ & $0.00 \mathrm{~d}$ & $0.00 \mathrm{~d}$ \\
\hline $\mathrm{LSD}_{(0.05)}$ & 1.72 & 1.41 & 1.99 & 3.22 & 2.31 & 2.99 & 3.13 & 4.24 \\
\hline $\mathrm{SE}_{(}( \pm)$ & 0.559 & 0.459 & 0.648 & 1.04 & 0.750 & 0.969 & 1.02 & 1.38 \\
\hline
\end{tabular}

$* *=$ Significant at $1 \%$ Level of Probability, $* \mathrm{~T}_{0}=$ Control, $\mathrm{T}_{1}=$ Antracol $70 \mathrm{WP}, \mathrm{T}_{2}=$ Ridomil Gold MZ $68 \mathrm{WP}, \mathrm{T}_{3}=$ Secure $600 \mathrm{WG}, \mathrm{T}_{4}=$ Bavistin DF and $\mathrm{T}_{5}=$ Dithane $\mathrm{M}-45$ 

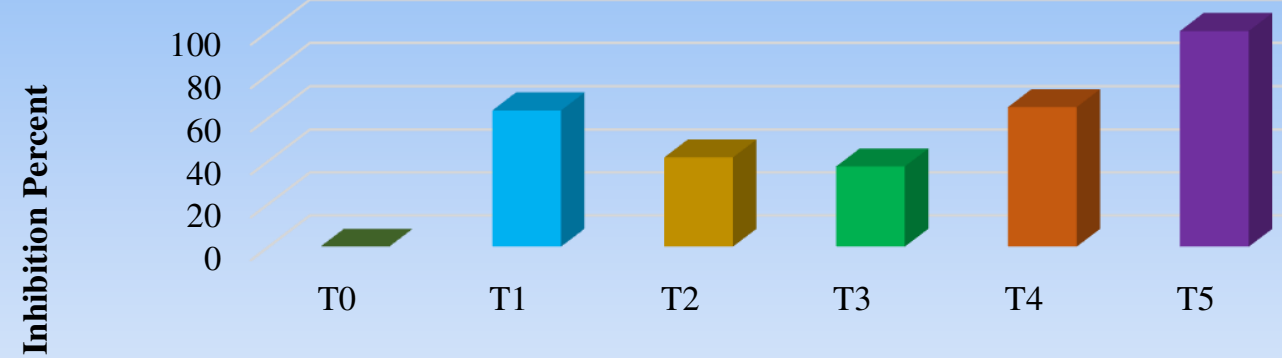

$\mathrm{T} 2$

T3

$\mathrm{T} 4$

T5

Treatments

$\because \mathrm{T} 0 \quad \mathrm{~T} 1 \quad \mathrm{~T} 2 \quad \mathrm{~T} 3 \quad \mathrm{~T} 4 \quad \square \mathrm{T} 5$

Fig 1: Effects of different fungicides on percent mycelial growth inhibition against Sclerotium rolfsii at 6 DAI (in vitro).

Here, $\mathrm{T}_{0}=$ Control, $\mathrm{T}_{1}=$ Antracol $70 \mathrm{WP}, \mathrm{T}_{2}=$ Ridomil Gold MZ $68 \mathrm{WP}, \mathrm{T}_{3}=$ Secure $600 \mathrm{WG}, \mathrm{T}_{4}=$ Bavistin DF and $\mathrm{T}_{5}=$ Dithane M-45. All the tested fungicides have strong effect on inhibition of mycelium growth against $S$. rolfsii in culture media. The highest percent of mycelial inhibition $(100 \%)$ was recorded in case of treatment T5 (Dithane M-45) followed by treatment T4 (Bavistin DF) $64.88 \%$, T1 (Antracol 70 WP) 63.33\%, T2 (Ridomil Gold MZ 68 WP) $41.55 \%$ and T3 (Secure $600 \mathrm{WG}$ ) 37.33\% at 6 DAI (Fig 1).

Our findings were supported by Sangeetha and Jahagirdar (2013). They reported that Mancozeb (Dithane M-45), Carbendazim, (Carbendazim + Mancozeb) and (Carboxin + Mancozeb) were found to be effective in inhibiting mycelial growth of some pathogens including S. rolfsii. Among the tested five fungicides Dithane M-45 and Bavistin were also found to be toxic which caused $100 \%$ inhibition in growth of $S$. rolfsii at $0.2 \%$ concentration. These two fungicides were also recorded as fungicidal in action at the same concentrations. Antracol $70 \mathrm{WP}$, Secure 600 WG and Ridomil Gold MZ 68 WP have proved to be poor in this respect and did not show significant percent of inhibition and it was found by Chaurasia (2014). This result is in agreement with some researcher's viz. Singh et al., (2012), Sheoraj et al. (2005), Bhise (2002) and Harlapur (1988).

3.2 In-vivo evaluation (Pot experiment) - Data recorded on mortality percent of collar rot disease of soybean plants as affected by the application of different fungicides were presented in Table 4. The effects of different treatments were recorded at 45 days after sowing (DAS) differed significantly as compared to control. The spraying of treatment T5 (Dithane M-45) gave the lowest mortality percent 27.28\%, T4 (Bavistin DF) 38.92\%, T1 (Antracol 70 WP) $43.42 \%$, T3 (Secure $600 \mathrm{WG}$ ) 46.18\% and T2 (Ridomil Gold MZ 68 WP) 50\%. The highest mortality percent was recorded in treatment $\mathrm{T} 0$ (Control) treatment 100\%. Among the treatments, T5 (Dithane M-45) gave the best result for reducing percent mortality $27.28 \%$ of Soybean plants. Fungicides have profound effect on reduction of Mortality percent of soybean plants cultured in pot. All the tested five fungicides significantly reduced the mortality percent of the plants. The reduction of mortality percent of treatment T5 (Dithane M-45) was $72.72 \%$, T4 (Bavistin DF) 61.08\%, T1 (Antracol $70 \mathrm{WP}$ ) 56.58\%, T3 (Secure $600 \mathrm{WG)} \mathrm{53.82 \% ,} \mathrm{T2}$ (Ridomil Gold MZ $68 \mathrm{WP}$ ) 50\% and T0 (Control) 0\% (Table 4). This data was obtained on November when temper-ature was $21^{\circ} \mathrm{C}$ and Relative humidity was $78 \%$. This result is in agreement with some researchers viz. Mollah, (2012), Madhavi and Bhattiprolu (2011), Dasgupta and Maiti (2008); Johnson and Reddy (2008); Yaqub and Shahzad (2006), Tiwari and Singh (2004), Singh and Singh (2004), Siddique et al. (2002), Sugavanam et al. (1994), Kulkarni et al. (1994).

Table 4: Effect of different fungicides on mortality percent of soybean plants (in pot experiment).

\begin{tabular}{|c|c|c|c|}
\hline Treatments & Healthy Plants & Dead Plants & Mortality Percent (\%) \\
\hline $\mathrm{T}_{0}$ & $2.00 \mathrm{c}$ & $2.00 \mathrm{~cd}$ & 100 \\
\hline $\mathrm{T}_{1}$ & $7.67 \mathrm{~b}$ & $3.33 \mathrm{~b}$ & 43.42 \\
\hline $\mathrm{T}_{2}$ & $2.00 \mathrm{c}$ & $1.00 \mathrm{~d}$ & 50 \\
\hline
\end{tabular}




\begin{tabular}{|c|c|c|c|}
\hline $\mathrm{T}_{3}$ & $4.33 \mathrm{c}$ & $2.00 \mathrm{~cd}$ & 46.18 \\
\hline $\mathrm{T}_{4}$ & $12.00 \mathrm{a}$ & $4.67 \mathrm{a}$ & 38.92 \\
\hline $\mathrm{T}_{5}$ & $11.00 \mathrm{a}$ & $3.00 \mathrm{bc}$ & 27.28 \\
\hline $\mathrm{LSD}_{0.05}$ & 2.37 & 1.18 & \\
\hline $\mathrm{SE}( \pm)$ & 0.770 & 0.384 & \\
\hline
\end{tabular}

Here, $\mathrm{T}_{0}=$ Control, $\mathrm{T}_{1}=$ Antracol $70 \mathrm{WP}, \mathrm{T}_{2}=$ Ridomil Gold MZ $68 \mathrm{WP}, \mathrm{T}_{3}=$ Secure $600 \mathrm{WG}, \mathrm{T}_{4}=$ Bavistin DF and $\mathrm{T}_{5}=$ Dithane M-45

On the other hand, Sharma and Ghosh (2017) reported collar rot disease yielded 55-95\% seedlings mortality of chickpea under heavy rainfall and high soil temperature $\left(25-30^{\circ} \mathrm{C}\right)$. From the findings of the present experiment it may be concluded that treatment Dithane M-45 was most effective under invitro condition as it has completely inhibited mycelial growth of $S$. rolfsii up to $100 \%$ and exhibited minimum mortality percent of Soybean plants at $0.2 \%$ concentration. From this experiment, it was observed that Dithane M-45 reduced the growth of $S$. rolfsii significantly in in-vitro and reduced collar rot disease incidence of soybean in vivo condition.

\section{CONCLUSION:}

From the findings of the present experiment it may be concluded that Dithane M-45 was found completely inhibited the mycelial growth of collar rot pathogen Sclerotium rolfsii in vitro and exhibited minimum mortality percent of Soybean plants at $0.2 \%$ concentration. Again Dithane M-45 also showed superior performance in reducing collar rot incidence of soybean in pot experiment.

\section{ACKNOWLEDGEMENTS:}

The authors hereby acknowledge the supports of Plant Pathology Division of Bangladesh Institute of Nuclear in Agriculture for giving us the opportunity to conduct this research work.

\section{CONFLICT OF INTERESTS:}

The author (s) declared no potential conflicts of the interest with respect to the research, authorship and/or publication of this article.

\section{REFERENCES:}

1. Ahmed F. (1980). Control of foot and root rot disease of wheat (Doctoral dissertation, MS thesis, Dept. of Plant Pathology Department, Bangladesh Agricultural University (BAU), Mymensingh).
2. Ahmed HU, Hossain MM. (1985). Final report of project crop disease survey and establishment of a herbarium at BARI. Plant. Path. Divn., BARI, Joydebpur,16-70.

3. Aken CN, Dasiell KE. (1991). First report of southern blight caused by $S$. rolfsii on soybean in Nigeria. Plant Disease, 75: 537. https://doi.org/10.1094/PD-75-0537D

4. BARC, (2012). Fertilizer Recommendation Guide, Bangladesh Agricultural Research Council, Farmgate, Dhaka 1215. 274p.

5. Baruah HK, Baruah P, Baruah A. (1980). Textbook of plant pathology, pp.498. Oxford and Ibh, publishing Co, New Delhi.

6. Bhise YP. (2002). Studies on management of collar rot of chickpea caused by Sclerotium rolfsii (Doctoral dissertation, Jnkvv, Jabalpur).

7. Chaurasia AK. (2014). Efficacy of antibiotics against Sclerotium rolfsii causings foot-rot of brinjal. Journal of Microbiology, 3(1): 1-4.

8. Dasgupta B, Maiti. (2008). Assessment of Phytophthora root rot of betel vine and its management using chemicals. Indian $J$. of Mycological Plant Pathology, 29: 91-95.

9. Fakir GA, Sarder MA, Gaffar, A, Ahmed MU. (1991). An annotated list of important disorders of important crop plants of Bangladesh. Pl. Quarantine Rev. Prog. Sponsored by the Ministry of Agriculture in coordination with CIDA \& DANIDA, 107.

10. FAO, (2013). The State of Food Insecurity in the World. The multiple dimensions of food security. Pp. 1-56. http://www.fao.org/3/a-i3434e.pdf

11. Giri B and Kapoor R. (2003). Influence of arbuscular mycorrhizal fungi and salinity on growth, biomass, and mineral nutrition of Acacia auriculiformis. Biology and Fertility of Soils, 38(3):170-175. https://doi.org/10.1007/s00374-003-0636-Z

12. Gomez KA Gomez AA. (1984). Statistical 
procedures for agricultural research. John Wiley \& Sons.

13. Gupta OM, Sharma ND.(2000). Occurrence of Sclerotinia stems rot of chickpea in Madhya Pradesh, India. International Chickpea and Pigeonpea Newsletter, (7).

14. Harlapur SI. (1988). Studies on some aspects of foot rot of wheat caused by Sclerotium rolfsii. M.Sc. (Agri.) Thesis, University of Agricultural Sciences, Dharwad.

15. Hossain MI, Matin MA, Alam MS, Ahmed M. (1992). Socio-Economic Study of Soybean in Some Selected Areas of Bangladesh. Bangladesh J. Argi. Res, 17(1): 7-12.

16. Johnson M, Reddy PN. (2008). Comparative efficacy of rhizosphere mycoflora, fungicides, insecticides and herbicides against groundnut stem rot caused by Sclerotium rolfsii. Annals of Plant Protection Sciences, 16(2): 414-418.

https://agris.fao.org/agris-search/search.do? recordID=IN2009000032

17. Keyser HH. (1992). Potential for increasing biological nitrogen fixation in soybean. Plant Soil, 141:119-135.

https://www.jstor.org/stable/42937999

18. Kokub D, Azam F, Hassan A, Ansar M, Asad MJ, Khanum A. (2007). Comparative growth, morphological and molecular characterization of indigenous Sclerotium rolfsii strains isolated from different locations of Pakistan. Pak. J. Bot., 39(5): 1849-66.

19. Kulkarni S, Hiremath RV, Padaganur GM. (1995). Diseases of potato and their management. Research Highlights on Potato. University of Agricultural Sciences, Dharwad, 22-30.

20. Kulkarni SA, Anahosur KH. (1994). Effect of Age of Groundnut Plant to Infection of Sclerotium rolfsii Sacc. A Causal Agent of Stem Rot Disease. Karnataka Journal of Agricultural Sciences, 7: 367-368.

http://14.139.155.167/test5/index.php/kjas/art icle/view/5998

21. Madhavi GB, Bhattiprolu SL. (2011). Integrated disease management of dry root-rot of chili incited by Sclerotium rolfsii. International Journal of Plant, animal and environmental sciences, 1(2): 31-37.

http://www.ijpaes.com/admin/php/uploads/10 8_pdf.pdf

22. Mollah MI. (2012). Investigation on The leaf rot and foot and root rot of betel vine (Piper betel L.) in Satkhira district of Bangladesh (Doctoral dissertation, MS Thesis, Dept. of Plant Pathology, Sher-eBangla Agricultural University, Sher-eBangla Nagar, Dhaka-1207).

23. Mondal MR, Wahhab MA. (2001). Production Technology of Crops. Oil seed Research Center, Bangladesh Agril. Res. Inst. Joydebpur, Gazipur, 1-10.

24. Mullen J. (2001). Southern blight, southern stems blight, white mold. The Plant Health Instructor, 10(1):104.

https://www.apsnet.org/edcenter/disandpath/f ungalbasidio/pdlessons/Pages/SouthernBlight aspx

25. Nene YL, Thapliyal PN. (1982). Fungicides in plant disease control, pp. 163. Oxford and IBH Publishing co. Pvt. Ltd. New Delhi. https://www.amazon.com/FungicidesPlant-Disease-Control-Thapliyal/dp/93864 79842

26. Patil MB, Rane, M. S. (1982). Incidence and control of Sclerotium wilt of groundnut. Pesticides, 23-24.

https://agris.fao.org/agris-search/search.do? recordID=US201301993280

27. Prabhu HV, Patil PV. (2004). Efficacy of chemical and biological seed dressers and host resistance in the management of collar rot of soybean caused by Sclerotium rolfsii Sacc. Soybean Research, 2, pp.41-45.

28. Pankaj A, Himani K, Vibhuti, Kiran, B. (2016). Germination and Seedling Growth of Pulse Crop (Vigna Spp.) as Affected by Soil Salt Stress. Current Agriculture Research Journal, 4(2): 159-170.

https://doi.org/10.12944/CARJ.4.2.05

29. Punja ZK. (1985). The biology, ecology, and control of Sclerotium rolfsii. Annual review of Phytopathology, 23(1):97-127. https://doi.org/10.1146/annurev.py.23.090185 .000525

30. Rahman L. (2003). Studies on the developpment of varieties, production technology, food and fish feed uses of soybean in Bangladesh (BAU-USDA Soybean Project 
BG-ARS 107), p6.

31. Rekha D, Patil MB, Shridhar Shetty P, Swamy KM, Rajini BG. (2012). In vitro screening of native Trichoderma isolates against Sclerotium rolfsii causing collar rot of ground nut. International Journal of Science and Nature, 3(1):117-20.

32. Sangeetha TV, Jahagirdar S. (2013). Screening fungicides against Sclerotium rolfsii, Rhizoctonia bataicola and Fusarium $s p$. causing root rot/wilt of soybean. BIOINFOLET-A Quarterly Journal of Life Sciences, 10(1a): 38-41.

33. Sekhar YC, Ahammed SK, Prasad TN, Devi RS. (2017). Morphological and pathogenic variability of Seclerotium rolfsii isolates causing stem rot in Groundnut. Int. J. Pure App. Biosci, 5(5): 478-487. http://dx.doi.org/10.18782/2320-7051.3003

34. Shahen MZ, Mahmud S, Uddin ME and Alam MS. (2019). Effect of antibiotic susceptibility and inhibitory activity for the control of growth and survival of microorganisms of extracts of Calendula officinalis, Eur. J. Med. Health Sci. 1(1), 19. https://doi.org/10.34104/ejmhs.0190109

35. Sharma M, Ghosh R. (2017). Heat and soil moisture stress differentially impact chickpea plant infection with fungal pathogens. In Plant tolerance to individual and concurrent stresses (pp. 47-57). Springer, New Delhi.

https://app.dimensions.ai/details/publication/p ub.1083420950

36. Siddique MA. (1997). Study on varietal reactions of brinjal to foot rot and its control through chemicals and organic soil amendments (Doctoral dissertation, Dept. of Plant Pathology. Bangladesh Agricultural University, Mymensingh. Bangladesh).

37. Siddique MAB, Meah MB, Siddiqua MK, Rahim, MA, Hoque, MM. (2002). Response of ten brinjal varieties to foot rot caused by Sclerotium rolfsii. Bangladesh Journal of Plant Pathology. 18(1/2): 77-81.

38. Singh A, Singh HB. (2004). Control of collar rot in mint (Mentha spp.) caused by Sclerotium rolfsii using biological means. Current science, 362-366.

https://www.jstor.org/stable/24108943

39. Singh S, Gumber RK, Sandhu JS, Bains TS, Sidhu PS, Singh I, Singh K. (2002). PDG4: A new multiple disease resistant desi chickpea variety for Punjab in India. International Chickpea and Pigeonpea Newsletter, 9: 6-8.

40. Singh SR, Singh SK, Pandey RK. (2012). Integrated management of collar rot of lentil caused by Sclerotium rolfsii. Inter J of Plant Protection, 5(2): 386-390.

41. Sheoraj S, Prajapati R. K, Srivastava SSL. (2005). Efficacy of fungicides against Sclerotium rolfsii causing collar rot in lentil, Farm Science Journal, 14(2): 68- 69.

42. Sugavanam V, Udaiyan K, Manian S. (1994). Effect of fungicides on vesiculararbuscular mycorrhizal infection and nodulation in groundnut (Arachis hypogea L.). Agriculture, ecosystems \& environment, 48(3):285-293.

https://doi.org/10.1016/0167-8809(94)90110-4

43. Tiwari RKS, Singh A. (2004). Efficacy of fungicides on Rhizoctonia solani and Sclerotium rolfsii and their effect on Trichoderma harzianum and Rhizobium leguminosarum. Journal of Mycology and Plant Pathology, 34(2): 482-485.

44. Vincent JM. (1927). Distortion of fungal hyphae in the presence of certain inhibitors. Nature, 59: 850. https://doi.org/10.1038/159850b0

45. Yaqub F, Shahzad S. (2006). Effect of fungicides on in vitro growth of Sclerotium rolfsii. Pakistan J of Botany, 38(3): 881.

https://www.researchgate.net/publication/266 $\underline{609012}$

Citation: Rahman MM, Hasna MK, Shumsun N, Hasan R, Islam MN, Kabir MH, and Delwar M Hossain. (2020). Evaluation of some fungicides against collar rot Disease of soybean. Am. J. Pure Appl. Sci., 2(5), 159-166. https://doi.org/10.34104/ajpab.020.01590166 @ @ 